\title{
A Shigella sonnei outbreak traced to imported basil - the importance of good typing tools and produce traceability systems, Norway, 2011
}

B R Guzman-Herrador (BernardoRafael.Guzman.Herrador@fhi.no) ${ }^{1,2}$, E Nilsen ${ }^{3,4}$, K S Cudjoe , L Jensvoll $^{6}$, J M Kvamme Kv, $^{7,8}$

Lindegård Aanstad 9 , B A Lindstedt ${ }^{10,11}, \mathrm{~K}_{\text {Nygård }}{ }^{1}$, G Severinsen ${ }^{12}, \varnothing$ Werner-Johansen $^{13}, A$ L Wester ${ }^{10}$, M Wiklund ${ }^{3}$, L Vold ${ }^{1}$

1. Department of Infectious Disease Epidemiology, Norwegian Institute of Public Health, Oslo, Norway

2. European Program for Intervention Epidemiology Training, European Centre for Disease Prevention and Control (ECDC), Stockholm, Sweden

3. Department of Microbiology and Infectious Disease Control, University Hospital of North Norway, Tromsø, Norway

4. Department of Medical Microbiology; More and Romsdal Health trust, Molde, Norway

5. Norwegian Veterinary Institute, Oslo, Norway

6. Norwegian Food Safety Authority, Head Office, Ås, Norway

7. Laboratory of Gastroenterology and Nutrition, Institute of Clinical Medicine, University of Troms $\varnothing$, Norway

8. Department of Gastroenterology, University Hospital of North Norway, Troms $\emptyset$, Norway

9. Norwegian Food Safety Authority, District Office, Troms $\emptyset$, Norway

10. Department of Food-borne Infections, Norwegian Institute of Public Health, Oslo, Norway

11. Unit of Gene Technology, Akershus University Hospital, Nordbyhagen, Norway

12. Municipality of Tromsø, Troms, Norway

13. Municipality of Sarpsborg, Østfold, Norway

Citation style for this article:

Guzman-Herrador BR, Nilsen E, Cudjoe KS, Jensvoll L, Kvamme JM, Lindegård Aanstad A, Lindstedt BA, Nygård K, Severinsen G, Werner-Johansen $\emptyset$, Wester AL, Wiklund M, Vold L. A Shigella sonnei outbreak traced to imported basil - the importance of good typing tools and produce traceability systems, Norway, 2011. Euro Surveill. 2013;18(49):pii=20650. Available online: http://www.eurosurveillance.org/ViewArticle.aspx?Articleld=20650

Article submitted on 30 November 2012 / published on 05 December 2013

On 9 October 2011, the University Hospital of North Norway alerted the Norwegian Institute of Public Health (NIPH) about an increase in Shigella sonnei infections in Troms $\varnothing$. The isolates had an identical 'multilocus variable-number tandem repeat analysis' (MLVA) profile. Most cases had consumed food provided by delicatessen X. On 14 October, new S. sonnei cases with the same MLVA-profile were reported from Sarpsborg, south-eastern Norway. An outbreak investigation was started to identify the source and prevent further cases. All laboratory-confirmed cases from both clusters were attempted to be interviewed. In addition, a cohort study was performed among the attendees of a banquet in Troms $\emptyset$ where food from delicatessen $X$ had been served and where some people had reported being ill. A trace-back investigation was initiated. In total, 46 cases were confirmed (Troms $\varnothing=$ 42; Sarpsborg= 4). Having eaten basil pesto sauce or fish soup at the banquet in Troms $\emptyset$ were independent risk factors for disease. Basil pesto was the only common food item that had been consumed by confirmed cases occurring in Troms $\varnothing$ and Sarpsborg. The basil had been imported and delivered to both municipalities by the same supplier. No basil from the specific batch was left on the Norwegian market when it was identified as the likely source. As a result of the multidisciplinary investigation, which helped to identify the source, the Norwegian Food Safety Authority, together with NIPH, planned to develop recommendations for food providers on how to handle fresh plant produce prior to consumption.

\section{Introduction}

Shigellosis is endemic throughout the world. Symptoms are usually mild but range from watery, selflimiting diarrhoea to life threatening dysentery [1]. Of four Shigella species, $S$. sonnei is the most frequently isolated in industrialised countries [2]. Symptoms of $S$. sonnei infection are usually milder than those caused by $S$. dysenteriae or flexneri [3]. The bacteria are transmitted by ingestion of contaminated food or water, or through person-to-person contact. The incubation period ranges from 12 hours to one week [4]. The infective dose is very low: ingestion of 100 to 200 microorganisms can lead to disease [3].

In the European Union (EU) shigellosis infections are relatively uncommon. With a rate of 1.64 cases per 100,000 population in 2010 , they are far less frequent than Campylobacter and Salmonella infections, which have respective incidences of 56.95 and 21.31 per 100,000 population [5]. In Norway, between 120 and 190 cases of shigellosis have been reported annually in the last ten years, corresponding to an incidence between 2.5 to 4.0 per 100,000 population. Only 10 to $20 \%$ of the cases are domestically acquired [6]. Imported fresh vegetables have been identified as the vehicle of several outbreaks over the last years $[7,8]$.

In order to control imported feed and food of non-animal origin, the European Commission Regulation (EC) No $669 / 2009$ specifies a list of risk products subjected to increased level of official controls upon entry into 
the European Economic Area, which includes Norway [9].

\section{The alert}

On 8 October 2011, clinicians at the University Hospital of North Norway in Troms $\emptyset$, northern Norway (2011 population: 68,200 inhabitants) [10], attended six patients with bloody diarrhoea. On 9 October, the hospital's Department of Microbiology and Infection Control confirmed three patients with $S$. sonnei infection. None of them had a travel history outside or within Norway in the previous week. The microbiologist on call reported the cluster to the Municipal Medical Officer in Troms $\emptyset$ and to the Department of Infectious Diseases Epidemiology at the Norwegian Institute of Public Health (NIPH), and isolates were forwarded to the National Reference Laboratory for Enteropathogenic Bacteria (NRL). The NRL verified the isolates as being S. sonnei with an identical multilocus variable-number tandem repeat analysis (MLVA) profile that had not been identified in Norway before. Concurrently, the Local Food Safety Authority in Troms $\emptyset$ interviewed the patients on food consumption, who reported having eaten at delicatessen $X$ in downtown Troms $\varnothing$ or having participated in social events with food provided by delicatessen $\mathrm{X}$ during the week before becoming sick. In addition, the owners of delicatessen $X$, who were also interviewed, had received complaints from customers who had fallen ill.

On 14 October, the Municipal Medical Officer in Sarpsborg (2011 population: 52,800) [10], 1,700 km south of Troms $\varnothing$, notified a second cluster of shigellosis, whereby none of the patients had a travel history to Troms $\varnothing$. S. sonnei isolates had the same MLVA profile as those from Troms $\emptyset$.

Since more than one county was affected, the further coordination of the investigation was transferred to the national level. NIPH, in collaboration with the Norwegian Veterinary Institute, the Norwegian and Local Food Safety Authorities, the Municipal Medical Officers of the municipalities involved, and the Department of Microbiology and Infection Control at the University Hospital of North Norway, investigated the outbreak to identify the source, implement control measures and prevent further cases.

\section{Methods}

\section{Epidemiological investigation}

A case was defined as (i) a person in Norway with laboratory-confirmed $S$. sonnei infection after 1 October 2011 with the MLVA profile identified in the outbreak with absence of travel history abroad, or (ii) a person who had an isolate with one-locus difference from the MLVA outbreak profile and an epidemiological link to (i). The Local Food Safety Authority interviewed cases in Troms $\varnothing$ by telephone using a standard food-borne disease trawling questionnaire to generate hypotheses about common exposures among cases. Once the suspicion was focused towards Delicatessen X, their menu was used as basis for the interviews.

In order to gather more information on the second cluster, NIPH interviewed all cases in Sarpsborg by telephone using the same food-borne disease trawling questionnaire looking for common exposures among them and to those in Tromsø.

\section{Cohort study in Tromsø}

Delicatessen $X$ provided a list of social events they catered for from 30 September to 8 October, including a banquet with 50 guests in Troms $\emptyset$ on 1 and 2 October. Since the organiser of the banquet had reported to the delicatessen that some of them had fallen ill, and this event included participation of a greater number of participants, the NIPH studied a cohort among the banquet attendees to identify risk factors for disease. For the cohort study we defined a 'probable case' as a person who developed diarrhoea (more than three loose stools in 24 hours) and fever (self-reported) up to seven days after the banquet.

On 14 October, the NIPH sent a link to a web-based questionnaire via e-mail to the attendees. It contained questions on demographic information, symptoms and food eaten. NIPH attempted to interview persons who had not replied within five days by phone. Attack rates and relative risks with $95 \%$ confidence intervals $(\mathrm{Cl})$ were calculated. Variables with p<0.1 in the univariate analysis were included in a multivariable logistic regression model, using. STATA 11.0 (Stata Corporation, College Station, TX, USA).

\section{Microbiological investigation}

The Department of Microbiology and Infection Control at University Hospital of North Norway identified the initial isolates as $S$. sonnei by fermentation tests, agglutination and Vitek 2 automated identification. They sent them to the NRL, where all Shigella spp. isolates identified in Norway are received for identification to species-level, O-serogrouping, antimicrobial resistance testing and MLVA-typing [11].

\section{TABLE 1}

Description of the laboratory-confirmed cases of Shigella sonnei infection in Tromsø $(\mathrm{n}=42)$ and Sarpsborg $(\mathrm{n}=4)$, Norway, October 2011

\begin{tabular}{|l|c|c|}
\hline Variable & Troms & Sarpsborg \\
\hline Sex & 24 & 3 \\
\hline Female & 18 & 1 \\
\hline Male & 41 & 46.5 \\
\hline Age (years) & $19-84$ & $45-64$ \\
\hline Median &
\end{tabular}


The Norwegian Veterinary Institute analysed, using a polymerase chain reaction (PCR)- based method elaborated by the Nordic Committee on Food Analysis, the food items served by Delicatessen X in Troms $\emptyset$ and those served in Sarpsborg. Specimens were analysed for Shigella spp., Enterobacteriaceae and thermotolerant coliforms [12-14].

\section{Trace-back investigation}

The Norwegian Food Safety Authority performed trace back of products and inspection of the premises where the food likely associated to this outbreak was distributed, prepared and served. The supplier of the relevant food items was contacted to document and provide an overview of the supply chain process.

\section{Results}

\section{Epidemiological investigation}

Forty-six cases with identical MLVA profile were reported: 42 cases linked to Troms $\varnothing$ and four to Sarpsborg (Table 1). None of them reported travel outside Norway during the week prior to the onset of symptoms.

Of the Troms $\emptyset$ cases, all were diagnosed in Troms $\emptyset$, with the exception of one who was diagnosed in Oslo, but reported travel to Troms $\emptyset$ in the previous week (Figure 1). The cases in Tromsø had isolates collected and tested for gastrointestinal pathogenic bacteria between 5 and 21 October and those in Sarpsborg between 11 and 25 October (Figure 2).

\section{Cluster in Tromsø}

The median age of all 42 cases in Troms $\emptyset$ was 41 years (range: 19-84 years); twenty-four of the cases were female (Table 1). The first case of the outbreak sought medical attention and was tested on 5 October and the last one on 21 October (Figure 2). In total, four patients were hospitalised. All of them were admitted during the first days of the outbreak and had bloody diarrhoea; fever and abdominal pain, with a mean C-reactive protein of $234 \mathrm{mg} / \mathrm{L}$ (range: $120-364 \mathrm{mg} / \mathrm{L}$; norm <10 mg/L). The mean length stay in hospital was 2.8 days (range: 1-4 days). Three of the hospitalised patients received antibiotic treatment and all the admitted patients recovered well.

The Local Food Safety Authority interviewed 38 of the 42 cases: 37 had eaten food containing pesto sauce made with fresh basil from the Delicatessen $X$.

\section{Cohort study in Tromsø}

Forty-two of the fifty banquet attendees answered the web-based questionnaire. Eleven met the probable case definition (attack rate: $26 \%$ ). All of them had diarrhoea. Frequent symptoms were also abdominal pain (8 persons) and fever and nausea (7 persons). The highest attack rate occurred among those aged 20 to 29 years $(4 / 11 ; 36 \%)$ although there were persons from all ages affected. Both sexes were equally affected.

\section{FIGURE 1}

Geographical distribution of Shigella sonnei infection cases by municipality of diagnosis, Norway, October 2011

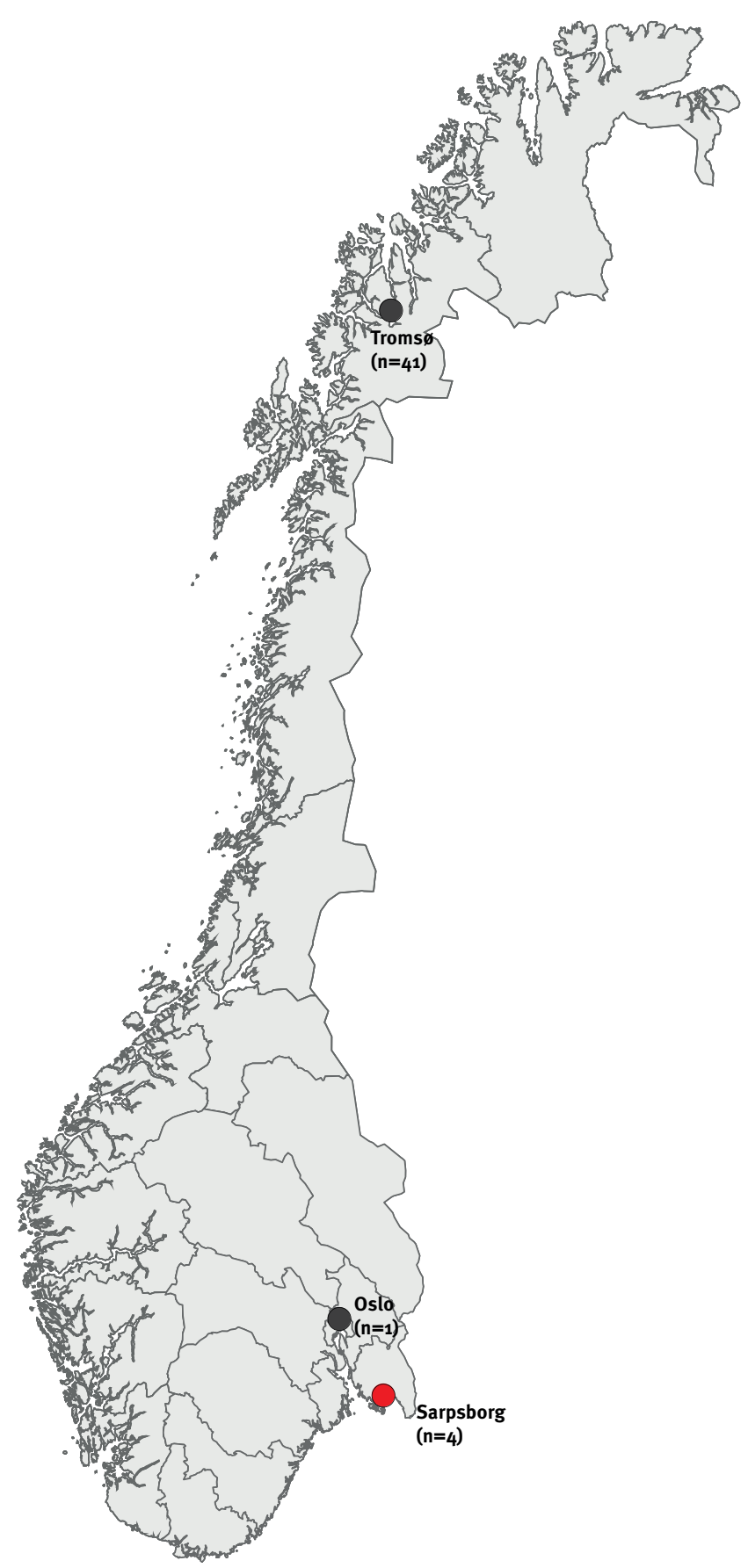

The case diagnosed with Shigella sonnei infection in Oslo, reported travel to Troms $\varnothing$ in the week before being diagnosed.

Six probable cases sought medical attention and three of them had a stool sample taken and were laboratory confirmed with the $S$. sonnei outbreak strain.

Ten banquet food items were significantly associated with disease in the univariate analysis (Table 2). Attendees exposed to basil pesto sauce had the 


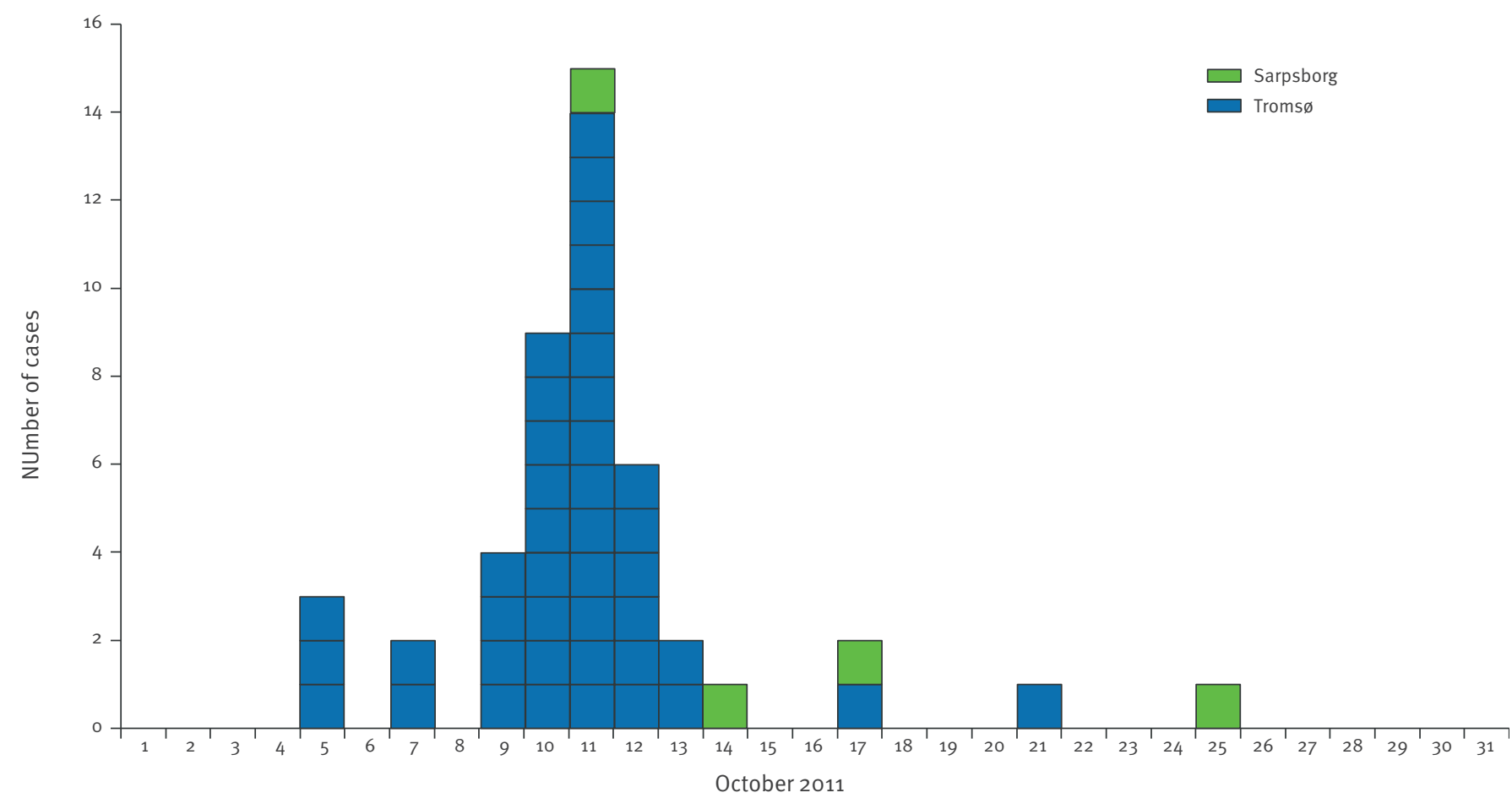

highest attack rate (78\%). Among the three food items with the highest relative risks (RR), basil pesto sauce had the smallest confidence interval. The lower limit of the confidence interval was higher than for any other item (RR: $5.4 ; 95 \% \mathrm{Cl}: 2.1-14 \cdot 4$ ).

Only two food items, fish soup (odds ratio (OR): 8.2; $95 \% \mathrm{Cl}: 1.1-61.1$ ) and basil pesto sauce (OR: $2.8 ; 95 \%$ $\mathrm{Cl}: 1.3-5.8)$ remained as independent risk factors for disease in the multivariate model (Table 3 ).

\section{Cluster in Sarpsborg}

Four cases were reported from Sarpsborg (Figure 1). The first case sought medical attention and was tested for gastrointestinal pathogenic bacteria on 11 October and the last one on 25 October (Figure 2). The median age was 46.5 years (range: $45-64$ years; Table 1 ). Three of the cases had eaten food containing fresh basil at the same restaurant in Sarpsborg ('restaurant Y') during the week before getting sick. The fourth case had not eaten in restaurant $Y$ but lived with one of the other cases, suggesting person to person transmission. None of them had any link to the cases reported in Troms $\emptyset$. None of these patients were hospitalised.

On 20 October, the NIPH posted an enquiry on the Epidemic Intelligence Information System (EPIS) hosted by the European Centre for Disease Prevention and Control to enquire if other European countries had reported clusters of $S$. sonnei infection. No information of any concomitant increase of cases of S. sonnei infections in other countries was received.

\section{Microbiological investigation}

The NRL received $48 \mathrm{~S}$. sonnei isolates from stool samples during October 2011. Of these, 46 were confirmed by microbiological characteristics to be part of the outbreak. The MLVA-profiles of these isolates were identical (44 isolates) or with one locus difference (2 isolates). This MLVA-profile differed to a great extent from earlier profiles available in the NRL database including approximately 600 isolates and 405 distinct profiles.

The Norwegian Veterinary Institute analysed 20 food specimens from Troms $\varnothing$ and Sarpsborg consisting of diverse vegetables, fresh herb spices, fruits, nuts, herb dressings (including basil for pesto) and spiced butter. All food specimens analysed were negative for Shigella spp., but harboured high Enterobacteriaceae counts with relatively low levels of thermotolerant coliforms. One basil pesto product in particular originating from Delicatessen $X$ had high levels of both Enterobacteriaceae and thermotolerant coliform counts.

\section{Trace-back investigation}

The Norwegian Food Safety Authority identified that the same supplier had provided fresh basil both to Delicatessen $X$ in Troms $\emptyset$ and to restaurant $Y$ in 
Univariate analysis of foods to which probable cases of Shigella sonnei infection ( $\mathrm{n}=11$ ) were exposed at a banquet in Tromsø, Norway, 1-2 October 2011

\begin{tabular}{|c|c|c|c|c|c|c|c|c|c|}
\hline \multirow[b]{2}{*}{ Food items } & \multicolumn{3}{|c|}{ Exposed } & \multicolumn{3}{|c|}{ Non exposed } & \multirow[b]{2}{*}{$\mathrm{RR}$} & \multirow[b]{2}{*}{$95 \% \mathrm{Cl}$} & \multirow{2}{*}{$\begin{array}{c}\text { Probable } \\
\text { cases } \\
\text { exposed } \\
(\%)\end{array}$} \\
\hline & $\begin{array}{c}\text { Probable } \\
\text { cases }\end{array}$ & Total & AR & $\begin{array}{c}\text { Probable } \\
\text { cases }\end{array}$ & Total & AR & & & \\
\hline Fish soup & 10 & 21 & 47.6 & 1 & 20 & 5.0 & 9.5 & $(1.3-67.8)$ & 90.9 \\
\hline Waldorf salad & 8 & 16 & 50.0 & 1 & 18 & 5.6 & 8.9 & $(1.3-64 \cdot 3)$ & 72.7 \\
\hline Basil pesto sauce & 7 & 9 & 77.8 & 4 & 28 & 14.3 & 5.4 & $(2.1-14.4)$ & 63.6 \\
\hline Roast beef & 7 & 14 & 50.0 & 2 & 19 & 10.5 & 4.8 & $(1.2-19.5)$ & 63.6 \\
\hline Herb dressing & 5 & 9 & 55.6 & 3 & 23 & 13.0 & 4.3 & $(1.3-14.2)$ & $45 \cdot 5$ \\
\hline Mustard sauce & 5 & 8 & 62.5 & 4 & 25 & 16.0 & 3.9 & $(1.4-11.1)$ & 45.5 \\
\hline Mousse & 6 & 9 & 66.7 & 4 & 23 & 17.4 & 3.8 & $(1.4-11.1)$ & 54.5 \\
\hline Banana cake & 6 & 9 & 66.7 & 5 & 27 & 18.5 & 3.6 & $(1.4-9)$. & 54.5 \\
\hline Raspberry sauce & 6 & 10 & 60 & 4 & 24 & 16.7 & 3.6 & $(1.3-10.1)$ & 54.5 \\
\hline Aioli sauce & 6 & 11 & 54.5 & 4 & 23 & 17.4 & 3.1 & $(1.1-8.9)$ & 54.5 \\
\hline
\end{tabular}

AR: attack rate; $\mathrm{Cl}$ : confidence interval, $\mathrm{RR}$ : relative risk.

For each food exposure, there were between one and 10 attendees missing a response because they did not recall having consumed or not a given food item.

Sarpsborg. The fresh basil was imported to Norway from Israel via the Netherlands. The Norwegian importer had received the basil on 25 September and delivered it to Tromsø on 27 September and to the restaurant in Sarpsborg on 27, 30 September and 4 October. No basil from the specific batch was left on the Norwegian market at the time when it was identified as the likely source of the outbreak. No further cases have been reported since 25 October.

On 11 November, following the identification of the implicated batch, the Norwegian Food Safety Authority generated a Rapid Alert System Food and Feed (RASFF) message about the basil, alerting other European countries.

\section{Discussion}

The results of the trawling interviews with the laboratory-confirmed cases in Troms $\emptyset$ made us hypothesise that an ingredient used in pesto served in Delicatessen $X$ could be the source of the outbreak. The results of the cohort study among the banquet attendees reinforced this hypothesis: eating basil pesto was an independent risk factor for disease and had the highest attack rate among exposed. In addition, basil pesto was the only common food item that had been consumed by the other laboratory-confirmed cases occurring in Troms $\varnothing$ and Sarpsborg. The findings from the cluster investigation in Sarpsborg strongly supported fresh basil as the vehicle ingredient of $S$. sonnei. The role of the other food item highlighted in the cohort study, fish soup, remains unclear. We considered whether an ingredient of the basil pesto could also be part of the fish soup.
The hypothesis was rejected as since the soup was not made by Delicatessen $X$, no common ingredients were used. None of the ingredients used in the soup had been eaten by the other laboratory-confirmed cases in Troms $\varnothing$. The role of the food handlers in a potential cross contamination of the two food items remains unclear.

This outbreak, with 46 laboratory-confirmed cases, is the second largest shigellosis outbreak reported by 2013 in Norway [15]. A larger S. sonnei infection outbreak occurred during 1994 and affected several countries in Europe, including Norway, Sweden and the United Kingdom. In the 1994 outbreak, there were 110 laboratory-confirmed cases within Norway and investigations traced it to imported iceberg lettuce [8].

\section{TABLE 3}

Independent risk factors determined by multivariate analysis for probable Shigella sonnei infections at a banquet in Tromsø, Norway, 1-2 October 2011

\begin{tabular}{|c|c|c|}
\hline Food items & OR $(95 \% \mathrm{Cl})$ & P value \\
\hline Fish soup & $8.2(1.1-61.1)$ & 0.04 \\
\hline Basil pesto sauce & $2.8(1.3-5.8)$ & 0.01 \\
\hline
\end{tabular}

OR: odds ratio; $\mathrm{Cl}$ : confidence interval. 
Several shigellosis outbreaks reported in Scandinavian countries have been associated with imported fruits or vegetables consumed raw or minimally-processed $[7,16]$. These food items might become contaminated during preparation by infected food handlers or during production by irrigation water contaminated with sewage [2]. The low infective dose and the considerable amount of fresh basil as an ingredient in pesto may have contributed to the large number of people becoming sick after eating basil pesto from delicatessen $X$ in Troms $\emptyset$, despite the growth-inhibitory effect of fresh herbs like basil or thyme on $S$. sonnei reported by some studies [17]. In this outbreak few affected individuals were admitted to hospital and no patients reported serious extra-intestinal symptoms. A noteworthy high $\mathrm{C}$-reactive protein in affected patients has also been reported in previous studies of shigellosis [18].

Despite the epidemiological evidence which seemed to conclusively identify basil as the likely source of the outbreak, none of the specimens were positive for Shigella. Detection of Shigella spp. in food items is difficult and no reliable method is available. High levels of both Enterobacteriaceae and thermotolerant coliform counts were obtained from a suspected pesto product. This indicates faecal contamination and makes contamination also by Shigella more likely.

The Norwegian importer decided to temporarily stop importing basil from the exporter upon the identification of the batch. The exporter went bankrupt, so no decision on when to resume importation was necessary. It is unclear at which point in the process of cultivation, production and importation of the basil the $S$. sonnei contamination may have occurred. Currently, basil from certain third countries outside EU/European Free Trade Association (EFTA), as Israel, are not included in the European Commission regulation (EC) No 669/2009 list of certain feed and food of non-animal origin subjected to increased level of official controls on imports. As a result of this investigation, the Norwegian Food Safety Authority, together with NIPH, planned to develop recommendations for food providers on how to handle fresh plant produce prior to consumption.

The multidisplinary collaboration during this investigation helped to identify and find the source of this outbreak of $S$. sonnei infection in Norway: The routine genotyping of all isolates of enteropathogenic bacteria in Norway was crucial to determine that the two clusters happening in two regions of the country were part of the same outbreak. The epidemiological and product trace-back investigations pointed to imported fresh basil as likely causing the outbreak.

\section{Acknowledgements}

We would like to acknowledge the following colleagues for their contribution to this outbreak investigation: Alicia Barrasa and Yvan Hutin from the European Programme for Intervention Epidemiology training and Berit Tafjord Heier, Emily Macdonald, Heidi Lange and Kirsten Konsmo from the
Norwegian Institute of Public Health. Parts of this work were presented as a poster at the Epidemic intelligence Service (EIS) Conference. Atlanta 22-26 April 2012.

\section{References}

1. European Centre for Disease Prevention and Control (ECDC). Shigellosis. Stockholm: ECDC. [Accessed o8 Apr 2013]. Available from http://www.ecdc.europa.eu/en/healthtopics/ shigellosis/Pages/index.aspx

2. Warren BR, Parish ME, Schneider KR. Shigella as a foodborne pathogen and current methods for detection in food. Crit Rev Food Sci Nutr. 2006;46(7):551-67.

http://dx.doi.org/10.1080/10408390500295458 PMid:16954064

3. Keusch G. Shigellosis. In: Brachman P, Abrutyn E, editors. Bacterial Infections of Humans. 4th ed. New York: Springer; 2009; p. 699-724.

http://dx.doi.org/10.1007/978-0-387-09843-2_33

4. Heymann DL, editor. Control of Communicable Diseases Manual. 19th ed. Washington DC: American Public Health Association; 2008.

5. European Centre for Disease Prevention and Control (ECDC). Annual Epidemiological Report 2012. Reporting on 2010 surveillance data and 2011 epidemic intelligence data. Stockholm: ECDC; 2013. Available from: http://www. ecdc.europa.eu/en/publications/Publications/AnnualEpidemiological-Report-2012.pdf

6. Vold L, Heier BT, Nygård K, Kapperud G. Årsrapport. Matbårne infeksjoner og utbrudd i 2011. [Annual report. Foodborne infections and outbreaks in 2011]; 2012. [Accessed 05 Apr 2013]. Norwegian. Available from: http://www.fhi.no/ dokumenter/295fd8bf97.pdf

7. Heier BT, Nygård K, Kapperud G, Linstedt BA, Johannessen GS, Blekkan H. Shigella sonnei infections in Norway associated with sugar peas, May-June 2009. Euro Surveill. 2009;14(24): pii=19243. Available from: http://www.eurosurveillance.org/ ViewArticle.aspx?Articleld $=19243$ PMid:19555603

8. Kapperud G, Rørvik LM, Hasseltvedt V, Hoiby EA, Iversen BG, Staveland K, et al.: Outbreak of Shigella sonnei infection traced to imported iceberg lettuce. J Clin Microbiol. 1995;33(3):609-14. PMid:7751364 PMCid:PMC227998

9. European Commission. Commission regulation (EC) No $669 / 2009$ of 24 July 2009 implementing Regulation (EC) No $882 / 2004$ of the European Parliament and of the Council as regards the increased level of official controls on imports of certain feed and food of non-animal origin and amending Decision 2006/504/EC. Official Journal of the European Union. Luxembourg: Publications Office of the European Union. 25.7.2009: L 194/11. Available from: http://eur-lex.europa.eu/ LexUriServ/LexUriServ.do?uri=0J:L:2009:194:0011:0021:EN:P DF

10. Statistics Norway. [Accessed 05 Apr 2012]. Available from: http://www.ssb.no

11. Rawal M, Hoff E, Aas-Pedersen L, Haugum K, Lindstedt BA. Rapid multiple-locus variable-number tandem-repeats analysis of Shigella spp. using multicolour capillary electrophoresis. J Microbiol Methods. 2010;83(3):279-85 http://dx.doi.org/10.1016/j.mimet.2010.10.006 PMid:20951171

12. Nordic Committee on Food Analysis (NMKL). Shigella spp. PCR method for detection in food. NMKL method No 174. 2nd Ed. Oslo: NMKL; 2002.

13. Nordic Committee on Food Analysis (NMKL). Enterobacteriace. Determination in foods and feed. NMKL method No 144. 2nd Ed. Oslo: NMKL; 2000.

14. Nordic Committee on Food Analysis (NMKL). Thermotolerant coliform and Escherichia coli. Enumeration in food and feed. NMKL method No 125. 4th Ed. Oslo: NMKL; 2005.

15. Norwegian Institute of Public Health (NIPH). Utbrudd av shigellose i Norge [Shigellosis outbreaks in Norway]. Oslo: NIPH. [Accessed 04 Apr 2013]. Norwegian. Available from: http://www.fhi.no/eway/default.aspx?pid=239\&trg=Content 6 601\&Main_6157=6263:0:25,6562\&MainContent_6263 $=6601: 0$ : 25,6928\&Content_6601=6430:77598::0:6596:20:::0:0

16. Lewis HC, Ethelberg S, Olsen KE, Nielsen EM, Lisby M, Madsen $\mathrm{SB}$, et al. Outbreaks of Shigella sonnei infections in Denmark and Australia linked to consumption of imported raw baby corn. Epidemiol Infect. 2009;137(3):326-34. http://dx.doi.org/10.1017/S0950268808001829 PMid:19134229 
17. Bagamboula CF, Uyttendaele M, Debevere J. Antimicrobial effect of spices and herbs on Shigella sonnei and Shigella flexneri. J Food Prot. 2003;66(4):668-73.

PMid:12696694

18. Khan WA, Salam MA, Bennish ML. C reactive protein and

prealbumin as markers of disease activity in shigellosis. Gut.

1995;37(3):402-5.

http://dx.doi.org/10.1136/gut.37.3.402

PMid:7590438 PMCid:PMC1382823 